\title{
Suggestions for further reading
}

This is only a selection from a large number of general and specialist studies available. Fuller bibliographies can be found in several of the works cited here, including the books by Biraben, Campbell and Poos.

Bean, J. M. W. 'Plague, population and decline in England in the later middle ages', Economic History Review 2nd series XV, 1963, pp. 423-38.

Benedictow, O. Plague in the late medieval Nordic Countries, Middelalderforlaget, Oslo, 1992.

Beresford, M. \& Hurst, J. G. Deserted Medieval Villages, Lutterworth Press, London, 1971.

Biraben, J-N. Les hommes et la peste en France et dans les pays européens et méditerranéens, 2 vols, École des Hautes Études en Sciences Sociales, Paris, 1975-6.

Bolton, J. L. The Medieval English Economy 1150-1500, Dent, London, 1980 (reprinted with supplement 1985).

Bowsky, W. M. (ed) The Black Death: a turning point, Holt, Rinehart \& Winston, New York, 1978.

Bridbury, A. R. 'The Black Death', Economic History Review, 2nd series XXVI, 1973, pp. 393-410.

- Before the Black Death', ibid XXX, 1977, pp. 393-410.

Britnell. R. H. 'Feudal reaction after the Black Death in the palatinate of Durham', Past Eं Present CXXVIII, 1990, pp. 28-47.

Campbell, A. The Black Death and Men of Learning, Columbia Univ. Press, New York, 1931.

Campbell, Bruce M. S. (ed) Before the Black Death: studies in the 'crisis' of the early fourteenth century, Manchester Univ. Press, Manchester, 1991.

Courtenay, W. J. 'The effect of the Black Death on English higher education', Speculum LV, 1980, pp. 696-714.

Coville, A. 'Écrits contemporains sur la peste de 1348 à 1350', Histoire Littéraire de la France XXXVII, 1938, pp. 325-390.

Crawfurd, R. Plague and Pestilence in Literature and Art, Oxford Univ. Press, Oxford, 1914.

Davies, R. A. 'The effect of the Black Death on the parish priests of the medieval diocese of Coventry and Lichfield', Historical Research LXII, 1989, pp. 85-90.

Dols, M. W. The Black Death in the Middle East, Princeton Univ. Press, Princeton, N.J., 1977.

Dyer, C. Standards of Living in the Later Middle Ages: social change in England, c. 12001520, Cambridge Univ. Press, Cambridge, 1989.

- 'The social and economic background to the rural revolt of 1381' in R. H. Hilton and T. H. Astons (eds), The English Rising of 1381, Cambridge Univ. Press, Cambridge, 1984, pp. 9-42. 
Gasquet, F. A. The Great Pestilence, Simpkin Marshall, Hamilton, Kent \& Co, London, 1893.

Goldberg, P. J. P. 'Mortality and economic change in the diocese of York, 1390-1514', Northern History XXIV, 1988, pp. 38-55.

Gottfried, R. S. Epidemic Disease in fifteenth-century England: the medieval response and its demographic consequence, Leicester Univ. Press, Leicester, 1978.

Harvey, B. F. 'The population trend in England between 1300 and 1348', Transactions of the Royal Historical Society, 5th series XVI, 1966, pp. 23-42.

Hatcher, John Plague, Population and the English Economy 1348- 1530, Macmillan, London \& Basingstoke, 1977.

- Mortality in the fifteenth century: some new evidence', Economic History Review, 2nd series XXXIX, 1986, pp. 19-38.

Levett, A. E. \& Ballard, A. 'The Black Death on the estates of the see of Winchester' in P. Vinogradoff (ed), Oxford Studies in Social and Legal History V, 1916.

Lomas, R. A. 'The Black Death in County Durham', Journal of Medieval History XV, 1989, pp. $127-40$.

Mate, M. 'Agrarian economy after the Black Death: the manors of Canterbury cathedral priory', Economic History Review 2nd series XXXVII, 1984, pp. 341-54.

Meiss, M. Painting in Florence and Siena after the Black Death, Princeton Univ. Press, Princeton, N.J., 1951.

Miller, E. \& Hatcher, J. Medieval England: rural society and economic change 1086-1348, Longman, London, 1978.

Ormrod, W. M. 'The English government and the Black Death of 1348-9' in idem (ed), England in the Fourteenth Century: proceedings of the 1985 Harlaxton Symposium, Boydell and Brewer, Woodbridge, 1986, pp. 175-88.

Poos, L. R. A Rural Society after the Black Death: Essex 1350-1525, Cambridge Univ. Press, Cambridge, 1991

Putnam, Bertha The Enforcement of the Statutes of Labourers during the first decade after the Black Death, 1349-1359, Columbia Univ. Press, New York, 1908.

Razi, Z. Life, Marriage $\Theta^{2}$ Death in a Medieval Parish: economy, society and demography in Halesowen 1270-1400, Cambridge Univ. Press, Cambridge, 1980.

Rees, W. 'The Black Death in England and Wales, as exhibited in manorial documents', Proceedings of the Royal Society of Medicine XVI, 1923, Section of the History of Medicine pp. 27-45.

— The Black Death in Wales', in R. W. Southern (ed), Essays in Medieval History, Macmillan, London, 1968, pp. 179-199.

Shrewsbury, J. F. D. A History of the Bubonic Plague in the British Isles, Cambridge Univ. Press, Cambridge, 1970.

Slack, Paul The Impact of Plague in Tudor and Stuart England, Oxford Univ. Press, Oxford, 1985 (reprinted with corrections, 1990).

Thompson, A. Hamilton 'The registers of John Gynewell, Bishop of Lincoln, for the years 1349-1350', Archaeological Journal LXVIII, 1911, pp. 301-360.

- 'The pestilences of the fourteenth century in the diocese of York', ibid LXXI, 1914, pp. 97-154.

Tristram, P. Figures of Life and Death in Medieval English Literature, Paul Elek, London, 1976.

Twigg, Graham The Black Death: a biological reappraisal, Batsford, London, 1984. 
[Wellcome Institute] The Pest Anatomized: five centuries of the plague in Western Europe, Wellcome Institute for the History of Medicine, London, 1985.

Williman, D. (ed) The Black Death: the impact of the fourteenth-century plague, Centre for Medieval and Early Renaissance Studies, Binghamton, 1982.

Ziegler, Philip The Black Death, Penguin, Harmondsworth, 1969 (reprinted with illustrations, Alan Sutton, Stroud, 1990). 
